\title{
An Analysis of India-Bahrain Trade Relations
}

\author{
Alok Kumar Yadav ${ }^{1}$, Dr. Umesh Chandra Yadav ${ }^{2}$ \\ ${ }^{l}$ (Research Scholar, Department of Economics, V.S.S.D College, C.S.J.M. University Kanpur, India) \\ ${ }^{2}$ (Associate Professor, Department of Economics, V.S.S.D College, C.S.J.M. University Kanpur, India)
}

\begin{abstract}
One of the distinctive features of the modern world is the rapid expansion of economic, scientific, technological and cultural ties among nations. Trade is an important and integral part of relations between different nations. India's trade relations with the Bahrain has transformed considerably over the years and the bilateral trade volume has surpassed US\$ 920.4 million mark in 2014, but the structure and pattern of trade is yet to be diversified. There are huge potentials for diversifying India's export structure based on certain new growth sectors in which India has global comparative advantage with respect to the Bahrain's imports structure.
\end{abstract}

Keywords: Comparative Advantage, Export, Import, Trade, Trade Balance

\section{Introduction}

India-Bahrain enjoys excellent bilateral relations characterised by cordial political, economic and cultural contacts. Our bilateral Trade and commercial exchanges go back to about 5,000 years ago tracing their origins to the period of Dilmun Civilisation in Bahrain to the era of Indus valley civilisation in India. Situated along popular trade routes between southern Iraq and India and Pakistan, Dilmun was a centre of business. Ancient Bahraini traders are believed to have carried out flourishing trade of Bahraini pearls with Indian spices from India. India-Bahrain economic and trade relations received fresh impetus from the oil boom of the early seventies. Relative prosperity and higher standard of living in Bahrain boosted global imports of goods and services, including from India. Bahrain Government's policy of industrial diversification also played an important role in enhancing economic co-operation between India and Bahrain. Bahrain serves as the gateway to the GCC market because of its location.

Why trade with Bahrain? Bahrain is the most mature, well established business hub with the largest financial institutions in the Gulf. With a track record of nearly 40 years and the highest number of licensed financial institutions, Bahrain is still the financial services leader in the entire region. Bahrain provides a free, open and transparent environment for businesses and has a globally competitive business environment which focuses on sustainability, skills and good governance. Bahrain's financial regulator is widely considered to be the best in the Middle East. Bahrain is uniquely located at the heart of the Gulf, which makes Bahrain the perfect hub to access the fast growing Gulf, Middle East and North Africa (MENA) markets. Since, reduction of trade barriers creates competitive pressures and the potential for technology transfer so as to lead to productivity gains and restructuring of an economy toward its comparative advantage. Bahrain and India has undertaken a series of economic reforms towards opening up of the economy in the decade of the eighties and nineties respectively. Notable among these has been the extensive effort to liberalise its international trade. It is therefore expected that trade liberalisation in India and Bahrain would have led to changes in the composition of exports so as to reflect India's and Bahrain's comparative advantage in the global economy. It is important therefore, to explore the structure of comparative advantage of India and Bahrain and the extent to which the two economies compete with each other in the global market for their commodities. This paper is the first to attempt a study on India-Bahrain bilateral economic relationship and a systematic evaluation of the similarities of the patterns of revealed comparative advantage by using the Balassa (1965) index for India and Bahrain in the global market.

\section{Objectives Of The Study}

Specifically the paper makes an attempt to explain the India-Bahrain trade relation and the structure of comparative advantage enjoyed by India and Bahrain in the global market. The main objectives of the study are:

1. To evaluate the structural dimensions of India's economic cooperation with Bahrain.

2. To identify the degree of India's trade intensity with Bahrain.

3. To investigate the nature of India's balance of trade with Bahrain.

4. The pattern of comparative advantage for India and Bahrain in the global market.

5. To analyse the leading commodities/sector in terms of their revealed comparative advantage in India and Bahrain. 


\section{Review Of The Literature}

Although there exists a vast literature on the India-Gulf trade relations, but the literature particularly on India-Bahrain trade relations is limited. Several studies have been undertaken using the concept of revealed comparative advantage. Balassa (1977) has undertaken an analysis of the pattern of comparative advantage of industrial countries for the period 1953 to 1971 . His result shows that while the extent of export diversification tends to increase with the degree of technological development a reversal takes place at higher levels.Elmadani (1999) work throw light on the commercial links between India and the Gulf countries. According to J.P.Joshi, "as many as 42 items of trade between India and the Gulf have been identified which include silver, copper, tortoise shell, ivory, cloth, carnelian, pearls, tin and precious stones".

Richardson \& Zhang (1999) have used the Balassa index of RCA for the U.S to analyse the patterns of variation across time, sectors and regions. They find the patterns to differ across different parts of the world, over time as also for different levels of aggregation of the export data.

The period of the seventeenth century has been known as the 'golden period' of Indian maritime trade because this was the time when the Indian merchants expanded their trade activities to almost every part of the Gulf (Chandra 1999).

Pradhan (2006) identifies another source of potential increase in Indo-GCC trade that emerges from the relatively smaller trade partners from GCC like Oman, Qatar, Bahrain and Kuwait. These four countries hold a share of only 14 percent in India's exports and 28 percent in India's imports from the region

The economic interaction between India and the Gulf countries is an important feature of Indo-Gulf relations which existed since the period of Indus Valley civilisation (Jain 2007). .

According to Abraham (2008) Karwar, Cannanore, Calicut and Cochin were important trading centre in Malabar from where spices, particularly, pepper, ivory, timber, pearls and gems were being exported to different parts of the Gulf region.

Rishabh \& Ranjan (2012) identify by how GCC economies are increasingly integrating with the emerging economies especially with those in Asia, providing an added reason for India-GCC trade relations to strengthen. Also, future course of the development of trade relations would depend upon how vigorously India pursues its policies of 'outward orientation' and 'commodity basket diversification' while GCC steers its 'look east' policies. In such a scenario it will be interesting to see if an FTA agreement is materialised and how it impacts the two-way trade flows between India and GCC.

Ladez \& Khan (2014) in his studies conclude that the fast economically growth of India and GCC countries made them mutually interdependence and the bilateral trade between the two regions has increased. But this interdependence was too light in the context of Bahrain's bilateral trade with India.

The dynamics of Gulf region comparative advantage has been analysed in several studies, but none of the study has analysed Bahrain particularly. Prominent among these is the Das \& Pradhan (2014) study. They conclude that though India's trade with the Gulf region has increased phenomenally over the last decade, but is predominantly dominated by exports and imports with the UAE and Saudi Arabia, neglecting other small countries. Thus, they suggest a holistic strategy as a specialised trade catalyst programme called "Gulf Direct" which should involve government authorities, private sector and trade associations and chambers, and to adopt certain policy catalysts which should solely focused on the Gulf region.

\section{India-Bahrain Trade: An Analysis \\ 1. Trends in India-Bahrain trade}

As is clear from the Table 1, the value of India's exports and imports to Bahrain has increased over the period. From \$ 204714514 in 2005 , exports rose to \$ 476030741 in 2014 . Imports during this period rose from \$ 164257468 to $\$ 444360319$. Though, total trade has increased by two and half times from $\$ 368971982$ in 2005 to $\$ 920391060$ in 2014 . But trade balance was positive in only three years viz. 2005,2013 and 2014 during the entire period 2005 to 2014. In all other years, deficits in balance of trade were recorded (Fig. 1.1).

Moreover, Fig. 1.2 portrays that the India's total trade with world has increased continuously except in year 2009 and 2014, but Bahrain share in India's total trade (in percentage) irregularly remains low standing at 0.1531, 0.1185 in 2005 and 2014 respectively, however, it reaches its highest at 0.3898 in 2008 .

\section{Trade composition}

\subsection{Sectoral orientation of exports}

Based on comparable data from ITC/UNCTAD/WTO, an analysis of the compositional changes in India's export basket to the Bahrain suggests that seven sectors at HS4 2-digit sectors account for 65 per cent of exports. These are 71-Natural or cultured pearls, precious or semi-precious stones, precious metals, metals clad with precious metal, and articles thereof; imitation jewellery; coin, 10-Cereals, 84-Nuclear reactors, boilers, machinery and mechanical appliances; parts thereof, 39-Plastics and articles thereof, 28-Inorganic chemicals; organic or inorganic compounds of precious metals, of rare-earth metals, of radioactive elements or of isotopes, 
85-Electrical machinery and equipment and parts thereof; sound recorders and reproducers, television image and sound recorders and reproducers, and parts and accessories of such articles and 73-Articles of iron or steel. The rest is accounted for by a whole range of sectors with medium and low shares (Table 2.1). This implies that India's export basket is not only characterised by high concentration but also thinly spread shares across a wide range of sectors. Fig. 2.1 portrays the share of each sector (HS4, 2 digits) in top 20 exports of India to Bahrain in 2005-06 and in 2014-15. The Fig. 2.1 shows that 84-Nuclear reactors, boilers, machinery and mechanical appliances; parts thereof constituted the main export sector in both years, though its share in top 20 exports declined from more than 15 percent to less than 9 percent between 2005 and 2014. On the other hand, the share of 71-Natural or cultured pearls, precious or semi-precious stones, precious metals, metals clad with precious metal, and articles thereof; imitation jewellery; coin, 10-Cereals, 39-Plastics and articles thereof and 28Inorganic chemicals; organic or inorganic compounds of precious metals, of rare-earth metals, of radioactive elements or of isotopes grow from 1.8584 to $17.7037,2.8143$ to $10.3249,2.6109$ to 8.526 and 1.1607 to 8.0663 respectively during the same period. Moreover, the Fig. 2.1 also shows that the share of 27-Mineral fuels, mineral oils and products of their distillation; bituminous substances; mineral waxes, 73-Articles of iron or steel, 72-Iron and steel and 7-Edible vegetables and certain roots and tubers reduces from 15.5 to $1.5827,9.0058$ to 5.2056, 6.6109 to 3.2963 and 4.8428 to 2.8928 respectively during 2005 and 2014 .

\subsection{Sectoral orientation of imports}

In 2005-06, the top 20 items of imports in India from Bahrain (in order of their value) is given in the Table 2.2. The composition of India's imports from the Bahrain suggest that three sectors at HS4 2-digit level account for an average share of 89 per cent of imports from the Bahrain over the period 2005-2014. These products belong to Chapters 27-Mineral fuels, mineral oils and products of their distillation; bituminous substances; mineral waxes, 76-Aluminium and articles thereof and 72-Iron and steel. The rest is accounted for by a whole range of sectors with low shares. Fig. 2.2 portrays the share of each sector (HS4, 2 digits) in top 20 imports to India from Bahrain in 2005-06 and in 2014-15. The Fig. 2.2 shows that 27-Mineral fuels, mineral oils and products of their distillation; bituminous substances; mineral waxes are the main import sector in both years and its share in top 20 exports increased from 38 percent to more than 49 percent between 2005 and 2014. On the other hand, the share of 72-Iron and steel, 47-Pulp of wood or of other fibrous cellulosic material; waste and scrap of paper or paperboard, 74 - Copper and articles thereof grow from 9.954 to $10.485,2.175$ to 2.7729 and 1.831 to 2.5374 respectively during the same period. Moreover, the Fig. 2.2 also shows that, though the share of 76-Aluminium and articles thereof and 25-Salt; sulphur; earths and stone; plastering materials, lime and cement reduces from 32.14 to 28.921 and 5.472 to 3.9009 respectively but its volume increases during 2005 and 2014 .

\section{Trade reciprocity index of India with Bahrain}

As is clear from the Table 3, the degree of trade reciprocity between India and Bahrain has not been constant over the period with values ranging between 0.5374 and 0.9547 . Initially from 0.6756 in 2005 it reached to its peak at 0.9547 in 2006. But then declined to 0.6942 in 2007 and roses until 2009 at 0.9341 ; thereafter there was a brief downward movement until 2014 at 0.5374 . The result indicates that though the TRI between India and Bahrain has reached a 'standard optimal level' in 2006 and 2009 (Fig. 3), but the global slowdown of 2008 and euro-crisis of 2012 has deteriorated the situation. Since, trade reciprocities tend to increase with bilateral trade intensities, hence further economic integration effort is needed to move towards balanced trade. Once the TRI has reached its maximum level, it may no longer show any long-term trend except to fluctuate around the higher end.

\section{Analysis of trade intensity between India and Bahrain}

Nevertheless, previous section says little about India's strong export and commodity sectors. In the light of an increasingly competitive international environment, it is useful to examine where India's trade intensity index with respect to the Bahrain. As is clear from the Table 4 and Fig. 4, the trade-intensity index across various years shows varying values. Starting from 2.61 in 2005, it reaches its highest to 3.15 in 2010 and lowest to 1.7 in 2014. In most of the year's TII was above 2 except in 2009, 2011 and 2014. The degree of export intensity was 2.27 in 2005, indicating strong India's representation in Bahrain's markets. However, since 2005 the index has kept on fluctuating, with all values falling between highest value of 2.68 in 2012 and lowest value of 1.38 in 2014. In terms of the import intensity index, India's imports from Bahrain exhibited an increasing trend from 1.11 in 2005 up to 6.2 in 2008. Since 2009, however, the index has shown a decreasing trend to its lowest at 0.89 in 2014 . However, since India's export intensity as well as import intensity with the Bahrain is above one for most of the years, means India's exports and imports are intense with Bahrain compared with rest of the world. The natural trading partner theory reveals countries tend to trade more with neighbours and close proximate partners. The Bahrain being geographically closer to India, value of these indices is likely to come down once it is adjusted for geographical distance. 


\section{Revealed comparative advantage (RCA) - The analysis}

As the name suggests, revealed comparative advantage indices are intended to reveal which sector/industries a country has a comparative advantage in producing goods from. Broad trends that emerge from this analysis for the two countries are discussed below:

\subsection{India's revealed comparative advantage}

As is evident from Table 5.1, India possesses a moderate revealed comparative advantage in several HS4 classification categories at a 2-digit aggregate level. The index of RCA is greater than one for 13 sectors in 2005 and 14 sectors in 2014 in the top 20 export sectors to Bahrain, indicating that India holds comparative advantage in these sectors in the world market As a percentage of total top 20 exports India enjoys comparative advantage in 11 commodities as 39.068 per cent in 2005 and 34.275 in 2014, which is to be expected given India's large and diverse economy. These commodities are: 71-Natural or cultured pearls, precious or semiprecious stones, precious metals, metals clad with precious metal, and articles thereof; imitation jewellery; coin, 52-Cotton, 10-Cereals, 9-Coffee, tea, mate and spices, 55-Man-made staple fibres, 62-Articles of apparel and clothing accessories, not knitted or crocheted, 3-Fish and crustaceans, molluscs and other aquatic invertebrates, 61-Articles of apparel and clothing accessories, knitted or crocheted, 7-Edible vegetables and certain roots and tubers, 73-Articles of iron or steel and 72-Iron and steel. Though 71-Natural or cultured pearls, precious or semi-precious stones, precious metals, metals clad with precious metal, and articles thereof; imitation jewellery; coin enjoyed the rank 1 with value of more than 7 in 2005 but in 2014, 52-Cotton has replaced its position as rank 1 with value higher than 8 in top 20 exports to Bahrain. Moreover, India also possesses a strong revealed comparative advantage in 10-Cereals with value of 5.11 in 2014.

In fact India has possessed an advantage in maximum categories except for 84-Nuclear reactors, boilers, machinery and mechanical appliances; parts thereof, 39-Plastics and articles thereof, 85-Electrical machinery and equipment and parts thereof; sound recorders and reproducers, television image and sound recorders and reproducers and 87-Vehicles other than railway or tramway rolling-stock, and parts and accessories thereof over the period 2005 and 2014. But in commodities as 28- Inorganic chemicals; organic or inorganic compounds of precious metals, of rare-earth metals, of radioactive elements or of isotopes and 8Edible fruit and nuts; peel of citrus fruit or melons articles India loses its comparative advantage position in 2005 to comparative disadvantage in 2014. However, India moves from comparative disadvantage in 2005 to comparative advantage in 2014 in two commodities viz. 2-Meat and edible meat offal and 27-Mineral fuels, mineral oils and products of their distillation; bituminous substances; mineral waxes.

\subsection{Bahrain's revealed comparative advantage}

In all Bahrain enjoys comparative advantage in the world market in 02 commodities in 2005 and 06 commodities in 2014 out of top 20 commodities exported by Bahrain to the India (Table 5.2). The commodities where Bahrain has higher comparative advantage in the world market are 27- Mineral fuels, mineral oils and products of their distillation and 76-Aluminium and articles thereof. But the value of 27-Mineral fuels, mineral oils and products of their distillation has decreased from 6.2623 in 2005 to 3.1550 in 2014. However, Bahrain has moved from comparative disadvantage in 2005 to comparative advantage in 2014 in four commodities viz. 72-Iron and steel, 83-Miscellaneous articles of base metal, 21-Miscellaneous edible preparations and 17-Sugars and sugar confectionery. As a percentage of total top 20 exports, Bahrain enjoys comparative advantage of 19.2704 per cent of 02 commodities in 2005 and 24.5194 percent of 06 commodities in 2014, indicating a relatively weak comparative advantage. However, Bahrain enjoyed a relatively strong comparative advantage in 76-Aluminium and articles thereof with a value of 13.0081 in 2005 and 15.0927 in 2014.

The commodities of Bahrain which were showing comparative disadvantage in the world market were: 25-Salt, sulphur, earth, stone, plaster, lime and cement, 47-Pulp of wood or of other fibrous cellulose material, 74-Copper and articles thereof, 39-Plastics and articles thereof, 85-Electrical, electronic equipment, 84-Nuclear reactors, boilers, machinery, etc, 70-Glass and glassware, 44-Wood and articles of wood, wood charcoal, 73Articles of iron or steel, 78-Lead and articles thereof, 28-Inorganic chemicals, precious metal compound, isotopes, 68-Articles of stone, plaster, cement, asbestos, mica or similar materials, 99-Commodities not elsewhere specified and 48-Paper and paperboard; articles of paper pulp, of paper or of paperboard.

\section{Data Base And Research Methodology}

The present study is based on secondary data, collected from ITC calculations based on UN COMTRADE statistics. The time period for the study is 2005-2014. The appropriate methodology employed is based on the objectives of the study. 


\section{Trade reciprocity:}

It refers to the mutual changes in trade policy which bring about changes in the volume of each country's imports that are of equal value to changes in the volume of its exports. The methodology was developed (Wadhva and Asher 1985) to measure reciprocity in the overall balance of trade between any two trade partner countries (or two regions). TRI (i.e. $\theta$ ) may take value between zero and one. Trade reciprocity index equal to one implies the state of perfectly balanced trade between the trading countries. Whereas, a zero trade reciprocity index implies completely unbalanced trade between the trading countries.Formally:

$$
\theta=1-\frac{\sum_{j=1}^{n}\left[\frac{\left|a_{i j}-a_{j i}\right|}{\left(a_{i j}-a_{j i}\right)} \cdot \sum_{i=1}^{n} a_{i j}\right]}{(n-1) \cdot \sum_{i=1}^{n} \sum_{j=1}^{n} a_{i j}}
$$

Where, $a_{i j}=$ exports of country $i$ (India) to partner $j$ (Bahrain); $a_{j i}=$ exports of country $j$ (Bahrain) to partner $i$ (India); $n=$ total number of countries involved in the context of the bilateral or regional; $\theta=$ the trade reciprocity index (TRI).

\section{Trade intensity index (TII):}

It is used to determine whether the value of trade between two countries is greater or smaller than would be expected on the basis of their importance in world trade. TII (Lei and Yao 2009) is defined as the share of one country's exports going to a partner divided by the share of world exports going to the partner. Range of values varies between 0 and +". It is calculated as:

$\mathrm{TII}_{\mathrm{IB}}=\left(\mathrm{X}_{\mathrm{IB}} / \mathrm{X}_{\mathrm{I}}\right) /\left(\mathrm{X}_{\mathrm{WB}} / \mathrm{X}_{\mathrm{W}}\right)$

Where, $X_{\mathrm{IB}}$ and $\mathrm{X}_{\mathrm{WB}}$ are the values of India's exports and of world exports to Bahrain and where $X_{\mathrm{I}}$ and $X_{\mathrm{W}}$ are India's total exports and total world exports respectively.

Trade Intensity Index is further divided in to Export Intensity Index (EII) and Import Intensity Index (III) for looking the pattern of exports and imports. Following (Kojima 1964), the index of trade intensity is restated as follows,

a. Export intensity index (EII) between India and the Bahrain is calculated as:

$\mathrm{EII}_{\mathrm{IB}}=\left(\mathrm{X}_{\mathrm{IB}} / \mathrm{X}_{\mathrm{I}}\right) /\left(\left(\mathrm{M}_{\mathrm{B}} /\left(\mathrm{M}_{\mathrm{W}}-\mathrm{M}_{\mathrm{I}}\right)\right)\right.$

Where, $X_{I B}=$ India's Export to the Bahrain; $X_{I}=$ India's total Export; $M_{B}=$ Total Import of the Bahrain; $M_{W}=$ Total World imports; $\mathrm{M}_{\mathrm{I}}=$ Total Imports of India.

b. Import intensity index (III) between India and the Gulf region is calculated as:

$\mathrm{III}_{\mathrm{IB}}=\left(\mathrm{M}_{\mathrm{IB}} / \mathrm{M}_{\mathrm{I}}\right) /\left(\left(\mathrm{X}_{\mathrm{B}} /\left(\mathrm{X}_{\mathrm{W}}-\mathrm{X}_{\mathrm{I}}\right)\right)\right.$

Where, $\mathrm{M}_{\mathrm{IB}}=$ Import of India from the Bahrain; $\mathrm{M}_{\mathrm{I}}=$ Total Import of India; $\mathrm{X}_{\mathrm{B}}=$ Total Export of the Bahrain; $\mathrm{X}_{\mathrm{W}}=$ Total World Export; $\mathrm{X}_{\mathrm{I}}=$ Total Export of India.

\section{Measuring revealed comparative advantage}

The current resurgence of interest in industrial policy sometimes confronts trade economists with demands to identify commodity/sectors of comparative advantage. A product with high RCA is competitive and can be exported to countries with low RCA. The traditional measure is the revealed comparative advantage (RCA) index (Balassa 1965). The concept of revealed comparative advantage pertains to the relative trade performance of individual countries in particular commodities. In this paper we use Balassa (1965) measure of relative export performance by country and industry/commodity, defined as a ratio of product $k$ 's share in country $i$ 's exports to its share in world trade. Formally:

$\mathrm{RCA}_{\mathrm{k}}^{\mathrm{i}}=\left(\mathrm{X}_{\mathrm{k}}^{\mathrm{i}} / \mathrm{X}^{\mathrm{i}}\right) /\left(\mathrm{X}_{\mathrm{k}} / \mathrm{X}\right)$

Where, $\mathrm{X}_{\mathrm{k}}^{\mathrm{i}}=$ country $i$ 's exports of good $k, \mathrm{X}^{\mathrm{i}}=\Sigma_{\mathrm{k}} \mathrm{X}_{\mathrm{k}}^{\mathrm{i}}$ its total exports, $\mathrm{X}_{\mathrm{k}}=\Sigma_{\mathrm{i}} \mathrm{X}_{\mathrm{k}}^{\mathrm{i}}$ world exports of good $k$ and $\mathrm{X}=\Sigma_{\mathrm{i}} \Sigma_{\mathrm{k}} \mathrm{X}_{\mathrm{k}}^{\mathrm{i}}$ total world exports.

The index value of the revealed comparative advantage (RCA) has a relatively simple interpretation. If it takes a value greater than unity, the country has a revealed comparative advantage in that product (or sector); whereas a value of less than unity implies that the country has a revealed comparative disadvantage in the product. The advantage of using the comparative advantage index is that it considers the intrinsic advantage of a particular export commodity and is consistent with changes in an economy's relative factor endowment and productivity. The disadvantage, however, is that it cannot distinguish improvements in factor endowments and pursuit of appropriate trade policies by a country. In this paper, RCA indices have been calculated for India and Bahrain across the top 20 chapters of the Harmonized System (HS -1996) classification for the year 2005 and 2014 to identify specific advantages in trade. The export data used here is for each commodity classification and in US\$ for the most recent year available for the given trading partner. Each commodity classification has been aggregated using HS4 classification to 2 digit level. 


\section{Tables and Figures}

Table 1: Growth in India's Trade with Bahrain

\begin{tabular}{|c|c|c|c|c|c|c|c|c|c|}
\hline Year & $\begin{array}{l}\text { India's Exports } \\
\text { to Bahrain } \\
\text { (value in USS) }\end{array}$ & $\begin{array}{l}\text { Growth } \\
\text { (percent) }\end{array}$ & $\begin{array}{l}\text { India's Imports } \\
\text { from Bahrain } \\
\text { (value in USS) }\end{array}$ & $\begin{array}{l}\text { Growth } \\
\text { (percent) }\end{array}$ & $\begin{array}{l}\text { Balance of trade } \\
\text { with Bahrain } \\
\text { (value in USS) }\end{array}$ & $\begin{array}{l}\text { Total trade with } \\
\text { Bahrain (value } \\
\text { in USS) }\end{array}$ & $\begin{array}{l}\text { Growth of } \\
\text { total trade } \\
\text { with Bahrain } \\
\text { (percent) }\end{array}$ & $\begin{array}{l}\text { India's } \\
\text { total } \\
\text { trade(valu } \\
\text { e in USS) }\end{array}$ & $\begin{array}{l}\text { Share in } \\
\text { India's } \\
\text { total trade } \\
\text { (percent) }\end{array}$ \\
\hline 1 & 2 & 3 & 4 & 5 & 6 & 7 & 8 & 9 & 10 \\
\hline 2005 & 204714514 & 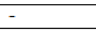 & 164257468 & 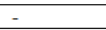 & $(+) 140457046$ & 368971982 & & $2.41 \mathrm{E}+11$ & 0.1531 \\
\hline 2006 & 145826849 & -28.7657 & 409590368 & 149.3587 & $(-) 263763519$ & 555417217 & 50.5310 & $2.99 \mathrm{E}+11$ & 0.1858 \\
\hline 2007 & 256434757 & 75.8488 & 564090406 & 37.7206 & (-) 307655649 & 820525163 & 47.7313 & $3.65 \mathrm{E}+11$ & 0.2249 \\
\hline 2008 & 283153844 & 10.4194 & 1657728479 & 193.8764 & $(-) 1374574635$ & 1940882323 & 136.5414 & $4.98 \mathrm{E}+11$ & 0.3898 \\
\hline 2009 & 253548349 & -10.4556 & 539820725 & -67.4361 & $(-) 286272376$ & 793369074 & -59.1233 & $4.43 \mathrm{E}+11$ & 0.1791 \\
\hline 2010 & 609004406 & 140.1926 & 663756045 & 22.9586 & (-) 54751639 & 1272760451 & 60.4248 & $5.70 \mathrm{E}+11$ & 0.2233 \\
\hline 2011 & 387245196 & -36.4134 & 683782606 & 3.0172 & $(-) 296537410$ & 1071027802 & -15.8500 & $7.63 \mathrm{E}+11$ & 0.1404 \\
\hline 2012 & 612051830 & 58.0528 & 910947201 & 33.2218 & $(-) 298895371$ & 1522999031 & 42.1998 & $7.79 \mathrm{E}+11$ & 0.1955 \\
\hline 2013 & 688695708 & 12.5224 & 593825420 & -34.8123 & (+) 94870288 & 1282521128 & -15.7898 & $8.03 \mathrm{E}+11$ & 0.1597 \\
\hline 2014 & 476030741 & -44.6746 & 444360319 & -25.1699 & $(+) 31670422$ & 920391060 & -28.2358 & $7.77 \mathrm{E}+11$ & 0.1185 \\
\hline
\end{tabular}

Source: Author's own calculation, computed from the data extracted from ITC calculations based on UN COMTRADE statistic

Table 2.1: India's Top 20 Export commodities to the Bahrain, 2005- 2014

\begin{tabular}{|c|c|c|c|c|c|c|c|c|}
\hline $\begin{array}{l}\text { Sr. } \\
\text { No. }\end{array}$ & $\begin{array}{l}\mathrm{HS} \\
\text { Code }\end{array}$ & Commodity & $\begin{array}{l}\text { Rank in } \\
2005-06\end{array}$ & $\begin{array}{l}\text { Value in 2005- } \\
06 \text { (USS) }\end{array}$ & $\begin{array}{l}\text { Share in } 2005 \\
\text { (percent) }\end{array}$ & $\begin{array}{l}\text { Rank in } \\
2014-15\end{array}$ & $\begin{array}{l}\text { Value in 2014- } \\
15 \text { (USS) }\end{array}$ & $\begin{array}{l}\text { Share in } 2014 \\
\text { (percent) }\end{array}$ \\
\hline 1 & 71 & $\begin{array}{l}\text { Natural or cultured pearls, precious or semi- } \\
\text { precious stones, precious metals, metals clad } \\
\text { with precious metal, and articles thereof; } \\
\text { mitation jewellery; coin }\end{array}$ & 17 & 2276359 & 1.8584 & 1 & 67670300 & 17.7037 \\
\hline 2 & 10 & Cereals & 12 & 3447367 & 2.8143 & 2 & 39465716 & 10.3249 \\
\hline$\frac{2}{3}$ & 84 & $\begin{array}{l}\text { Nuclear reactors, boilers, machimery and } \\
\text { mechanical appliances; parts thereof }\end{array}$ & 2 & 18970553 & 15.487 & 3 & 34324494 & 8.98 \\
\hline 4 & 39 & Plastics and articles thereof & 13 & 3198166 & 2.6109 & 4 & 32590154 & 8.526 \\
\hline 5 & 28 & $\begin{array}{l}\text { Inorganic chemicals; organic or inorganic } \\
\text { compounds of precious metals, of rare-earth } \\
\text { metals, of radioactive elements or of isotopes }\end{array}$ & 18 & 1421664 & 1.1607 & 5 & 30832294 & 8.0663 \\
\hline 6 & 85 & $\begin{array}{l}\text { Electrical machinery and equipment and parts } \\
\text { thereof, sound recorders and reproducers, } \\
\text { television image and sound recorders and } \\
\text { reproducers, and parts and accessories of such } \\
\text { articles }\end{array}$ & 7 & 5819099 & 4.7505 & 6 & 22849868 & 5.978 \\
\hline 7 & 73 & Articles of iron or steel & 4 & 11031530 & 9.0058 & 7 & 19897718 & 5.2056 \\
\hline$\frac{1}{8}$ & 52 & Cotton & $\frac{4}{3}$ & $\frac{11051500}{21171919}$ & $\frac{9.0050}{17.2841}$ & $\frac{1}{8}$ & 16609543 & 4.3533 \\
\hline 9 & 87 & $\begin{array}{l}\text { Vehicles other than railway or tramway rolling- } \\
\text { stock, and parts and accessories thereof }\end{array}$ & 11 & 3646282 & 2.9768 & 9 & 15848089 & 4.1461 \\
\hline 10 & 2 & Meat and edible meat offal & 9 & 3837534 & 3.1329 & 10 & 14301744 & 3.7415 \\
\hline 11 & 62 & $\begin{array}{l}\text { Articles of apparel and clothing accessories,not } \\
\text { knitted or crocheted }\end{array}$ & 8 & 4809725 & 3.9266 & 11 & 13344141 & 3.4911 \\
\hline 12 & 72 & Iron and steel & 5 & 8097882 & 6.6109 & 12 & 12599494 & 3.2963 \\
\hline 13 & 8 & $\begin{array}{l}\text { Edible fruit and nuts; peel of citrus fruit or } \\
\text { melons }\end{array}$ & 10 & 3715459 & 3.0331 & 13 & 11212975 & 2.9335 \\
\hline 14 & 7 & Edible vegetables and certain roots and tubers & 6 & 5932144 & 4.8428 & 14 & 11057059 & 2.8928 \\
\hline 15 & 61 & $\begin{array}{l}\text { Articles of apparel and clothing accessories, } \\
\text { knitted or crocheted }\end{array}$ & 15 & 2413047 & 1.97 & 15 & 8660215 & 2.2657 \\
\hline 16 & 55 & Man-made staple fibres & 19 & 977020 & 0.7977 & 16 & 7338771 & 1.92 \\
\hline 17 & 27 & $\begin{array}{l}\text { Mineral fuels, mineral oils and products of their } \\
\text { distillation; bituminous substances; mineral } \\
\text { waxes }\end{array}$ & 1 & 18983515 & 15.5 & 17 & 6049533 & 1.5827 \\
\hline 18 & 17 & Sugars and sugar confectionery & 20 & 113187 & 0.0924 & 18 & 5967615 & 1.5612 \\
\hline 19 & 9 & Coffee, tea, mate and spices & 16 & 2246449 & 1.84 & 19 & 5901931 & 1.544 \\
\hline 20 & 3 & $\begin{array}{l}\text { Fish and crustaceans, molluscs and other } \\
\text { aquatic invertebrates }\end{array}$ & 14 & 384771 & 0.3141 & 20 & 5717068 & 1.5 \\
\hline
\end{tabular}

Source: Author's own calculation, computed from the data extracted from ITC calculations based on UN COMTRADE statistic.

Table 2.2: India's Top 20 Import commodities from Bahrain, 2005-2014

\begin{tabular}{|c|c|c|c|c|c|c|c|c|}
\hline Sr. No. & HS Code & Commodity & $\begin{array}{l}\text { Rank in } \\
2005-06\end{array}$ & $\begin{array}{l}\text { Value in 2005- } \\
06 \text { (US S) }\end{array}$ & $\begin{array}{l}\text { Share in } 2005 \\
\text { (percent) }\end{array}$ & $\begin{array}{l}\text { Rank in } \\
2014-15\end{array}$ & $\begin{array}{l}\text { Value in 2014- } \\
15 \text { (USS) }\end{array}$ & $\begin{array}{l}\text { Share in } 2014 \\
\text { (percent) }\end{array}$ \\
\hline 1 & 27 & $\begin{array}{l}\text { Mineral fuels, mineral oils and products of their } \\
\text { distillation; bituminous substances; mineral } \\
\text { waxes }\end{array}$ & 1 & 61604689 & 38.26 & 1 & $2.15 \mathrm{E}+08$ & 49.06 \\
\hline 2 & 76 & Aluminium and articles thereof & 2 & 51758338 & 32.14 & 2 & $1.27 \mathrm{E}+08$ & 28.921 \\
\hline 3 & 72 & Iron and steel & 3 & 16028837 & 9.954 & 3 & 45882420 & 10.485 \\
\hline 4 & 25 & $\begin{array}{l}\text { Salt, sulphur; earths and stone; plastering } \\
\text { materials, lime and cement }\end{array}$ & 5 & 8810672 & 5.472 & 4 & 17070419 & 3.9009 \\
\hline 5 & 47 & $\begin{array}{l}\text { Pulp of wood or of other fibrous cellulosic } \\
\text { material; waste and scrap of paper or } \\
\text { paperboard }\end{array}$ & 6 & 3501781 & 2.175 & 5 & 12133866 & 2.7729 \\
\hline 6 & 74 & Copper and articles thereof & 7 & 2948893 & 1.831 & 6 & 11103760 & 2.5374 \\
\hline 7 & 39 & Plastic and articles thereof. & 12 & 100902 & 0.063 & 7 & 3263043 & 0.7457 \\
\hline 8 & 85 & $\begin{array}{l}\text { Electrical machinery and equipment and parts } \\
\text { thereor; sound recorders and reproducers, } \\
\text { television image and sound recorders and } \\
\text { reproducers, and parts. }\end{array}$ & 10 & 301987 & 0.188 & 8 & 1945860 & 0.4447 \\
\hline 9 & 84 & $\begin{array}{l}\text { Nuclear reactors, boilers, machinery and } \\
\text { mechanical appliances; parts thereof. }\end{array}$ & 11 & 3082 & 0.002 & 9 & 1142579 & 0.2611 \\
\hline 10 & 70 & Glass and glassware. & 17 & 184649 & 0.115 & 10 & 1063290 & 0.243 \\
\hline 11 & 21 & Miscellaneous edible preparations. & 20 & 0 & 0 & 11 & 930543 & 0.2127 \\
\hline 12 & 44 & Wood and articles of wood; wood charcoal. & 19 & 145 & $9 \mathrm{E}-05$ & 12 & 723516 & 0.1653 \\
\hline 13 & 73 & Articles of iron or steel & 16 & 711859 & 0.442 & 13 & 322855 & 0.0738 \\
\hline 14 & 78 & Lead and articles thereof. & 9 & 24531 & 0.015 & 14 & 267451 & 0.0611 \\
\hline 15 & 83 & Miscellaneous articles of base metal. & 15 & 2192987 & 1.362 & 15 & 142632 & 0.0326 \\
\hline 16 & 28 & $\begin{array}{l}\text { Inorganic chemicals; organic or inorganic } \\
\text { compounds of precious metals, of rare-earth } \\
\text { metals, or radi. Elem. Or of isotopes. }\end{array}$ & 4 & 12776642 & 7.935 & 16 & 134740 & 0.0308 \\
\hline 17 & 68 & $\begin{array}{l}\text { Articles of stone, plaster, cement, asbestos, mica } \\
\text { or similar materials. }\end{array}$ & 14 & 315 & $2 \mathrm{E}-06$ & 17 & 75494 & 0.0173 \\
\hline 18 & 99 & Miscellaneous goods. & 8 & 4017 & $3 \mathrm{E}-05$ & 18 & 74067 & 0.0169 \\
\hline 19 & 17 & Sugars and sugar confectionery. & 18 & 65299 & 0.041 & 19 & 67770 & 0.0155 \\
\hline 20 & 48 & $\begin{array}{l}\text { Paper and paperboard; articles of paper pulp, of } \\
\text { paper or of paperboard }\end{array}$ & 13 & 6722 & 4E-05 & 20 & 8208 & 0.0019 \\
\hline
\end{tabular}

Source: Author's own calculation, computed from the data extracted from ITC calculations based on UN COMTRADE statistic. 
Table 3: Trade Reciprocity Index of India with Bahrain

\begin{tabular}{|l|l|}
\hline Year & $\boldsymbol{T R I}_{\boldsymbol{I B}}$ \\
\hline 2005 & 0.6756 \\
\hline 2006 & 0.9547 \\
\hline 2007 & 0.6942 \\
\hline 2008 & 0.7360 \\
\hline 2009 & 0.9341 \\
\hline 2010 & 0.8029 \\
\hline 2011 & 0.8721 \\
\hline 2012 & 0.7019 \\
\hline 2013 & 0.6018 \\
\hline 2014 & 0.5374 \\
\hline
\end{tabular}

Source: Author's own calculation, computed from the data extracted from ITC calculations based on UN COMTRADE statistic.

Table 4: India's annual Trade Intensity with Bahrain during 2005-2014

\begin{tabular}{|l|l|l|l|}
\hline Year & $\boldsymbol{T I I}_{\boldsymbol{I B}}$ & $\boldsymbol{E I I}_{\boldsymbol{I}}$ & $\boldsymbol{I I I}_{\boldsymbol{I B}}$ \\
\hline 2005 & 2.6184 & 2.2731 & 1.11452 \\
\hline 2006 & 2.106 & 1.6484 & 2.34172 \\
\hline 2007 & 2.8688 & 2.1497 & 2.57816 \\
\hline 2008 & 2.0405 & 1.3714 & 6.20971 \\
\hline 2009 & 1.6705 & 1.491 & 2.85475 \\
\hline 2010 & 3.1565 & 2.6201 & 1.73275 \\
\hline 2011 & 1.9073 & 1.316 & 1.14486 \\
\hline 2012 & 2.4307 & 2.6852 & 1.91237 \\
\hline 2013 & 2.4336 & 2.0243 & 1.03678 \\
\hline 2014 & 1.7049 & 1.3831 & 0.89871 \\
\hline
\end{tabular}

Source: Author's own calculation, computed from the data extracted from ITC calculations based on UN COMTRADE statistic.

Table 5.1: India's Top 20 Export Commodities (to Bahrain) RCA Index Values

\begin{tabular}{|c|c|c|c|c|c|}
\hline SNo. & Classification & $\begin{array}{l}\text { HS } \\
\text { Code }\end{array}$ & Commodity & $\begin{array}{l}\text { RCA } \quad \text { of } \\
\text { India } \\
(2005)\end{array}$ & $\begin{array}{l}\text { RCA of } \\
\text { India } \\
(2014)\end{array}$ \\
\hline 1 & $\mathrm{H} 4$ & 71 & $\begin{array}{l}\text { Natural or cultured pearls, precious or semi-precious stones, } \\
\text { precious metals, metals clad with precious metal, and articles } \\
\text { thereof; imitation jewellery; coin }\end{array}$ & 7.4894 & 3.0171 \\
\hline 2 & $\mathrm{H} 4$ & 84 & $\begin{array}{l}\text { Nuclear reactors, boilers, machinery and mechanical appliances; } \\
\text { parts thereof }\end{array}$ & 0.2913 & 0.3638 \\
\hline 3 & $\mathrm{H} 4$ & 10 & Cereals & 4.5427 & 5.1139 \\
\hline 4 & $\mathrm{H} 4$ & 39 & Plastics and articles thereof & 0.6653 & 0.5203 \\
\hline 5 & $\mathrm{H} 4$ & 85 & $\begin{array}{l}\text { Electrical machinery and equipment and parts thereof; sound } \\
\text { recorders and reproducers, television image and sound recorders } \\
\text { and reproducers, and parts and accessories of such articles }\end{array}$ & 0.1808 & 0.2027 \\
\hline 6 & $\mathrm{H} 4$ & 73 & Articles of iron or steel & 1.661 & 1.4157 \\
\hline 7 & $\mathrm{H} 4$ & 28 & $\begin{array}{l}\text { Inorganic chemicals; organic or inorganic compounds of } \\
\text { precious metals, of rare-earth metals, of radioactive elements or } \\
\text { of isotopes }\end{array}$ & 1.1063 & 0.7328 \\
\hline 8 & $\mathrm{H} 4$ & 87 & $\begin{array}{l}\text { Vehicles other than railway or tramway rolling-stock, and parts } \\
\text { and accessories thereof }\end{array}$ & 0.3637 & 0.6178 \\
\hline 9 & $\mathrm{H} 4$ & 2 & Meat and edible meat offal & 0.9526 & 2.3281 \\
\hline 10 & $\mathrm{H} 4$ & 62 & $\begin{array}{l}\text { Articles of apparel and clothing accessories, not knitted or } \\
\text { crocheted }\end{array}$ & 3.4604 & 2.4444 \\
\hline 11 & $\mathrm{H} 4$ & 72 & Iron and steel & 1.5992 & 1.3511 \\
\hline 12 & $\mathrm{H} 4$ & 52 & Cotton & 5.482 & 8.3635 \\
\hline 13 & $\mathrm{H} 4$ & 8 & Edible fruit and nuts; peel of citrus fruit or melons & 1.835 & 0.9579 \\
\hline 14 & $\mathrm{H} 4$ & 7 & Edible vegetables and certain roots and tubers & 1.7226 & 1.0525 \\
\hline 15 & $\mathrm{H} 4$ & 55 & Man-made staple fibres & 2.9773 & 3.0736 \\
\hline 16 & $\mathrm{H} 4$ & 61 & Articles of apparel and clothing accessories, knitted or crocheted & 2.492 & 1.9424 \\
\hline 17 & $\mathrm{H} 4$ & 3 & Fish and crustaceans, molluscs and other aquatic invertebrates & 2.6993 & 2.9718 \\
\hline 18 & $\mathrm{H} 4$ & 17 & Sugars and sugar confectionery & 0.3417 & 1.7361 \\
\hline 19 & $\mathrm{H} 4$ & 9 & Coffee, tea, mate and spices & 4.9421 & 3.5290 \\
\hline 20 & $\mathrm{H} 4$ & 27 & $\begin{array}{l}\text { Mineral fuels, mineral oils and products of their distillation; } \\
\text { bituminous substances; mineral waxes }\end{array}$ & 0.8846 & 1.3488 \\
\hline
\end{tabular}

Source: Author's own calculation, computed from the data extracted from ITC calculations based on UN COMTRADE statistic. 
Table 5.2: Bahrain's Top 20 Export Commodities (to India's) RCA Index Values

\begin{tabular}{|c|c|c|c|c|c|}
\hline SNo. & Classification & $\begin{array}{l}\text { HS } \\
\text { Code }\end{array}$ & Commodity & $\begin{array}{l}\text { RCA of } \\
\text { Bahrain } \\
(2005)\end{array}$ & $\begin{array}{l}\text { RCA of } \\
\text { Bahrain } \\
(2014)\end{array}$ \\
\hline 1 & $\mathrm{H} 4$ & 27 & Mineral fuels, mineral oils and products of their distillation & 6.2623 & 3.1550 \\
\hline 2 & $\mathrm{H} 4$ & 76 & Aluminium and articles thereof & 13.0081 & 15.0927 \\
\hline 3 & $\mathrm{H} 4$ & 72 & Iron and steel & 0.0678 & 1.4867 \\
\hline 4 & $\mathrm{H} 4$ & 25 & Salt, sulphur, earth, stone, plaster, lime and cement & 0.0584 & 0.0566 \\
\hline 5 & $\mathrm{H} 4$ & 47 & Pulp of wood or of other fibrous cellulose material & 0.067 & 0.1019 \\
\hline 6 & $\mathrm{H} 4$ & 74 & Copper and articles thereof & 0.0509 & 0.0451 \\
\hline 7 & $\mathrm{H} 4$ & 39 & Plastics and articles thereof & 0.1614 & 0.3638 \\
\hline 8 & $\mathrm{H} 4$ & 85 & Electrical, electronic equipment & 0.0218 & 0.1934 \\
\hline 9 & $\mathrm{H} 4$ & 84 & Nuclear reactors, boilers, machinery, etc & 0.0776 & 0.5049 \\
\hline 10 & $\mathrm{H} 4$ & 70 & Glass and glassware & 0.0291 & 0.7064 \\
\hline 11 & $\mathrm{H} 4$ & 21 & Miscellaneous edible preparations & 0.0447 & 2.3747 \\
\hline 12 & $\mathrm{H} 4$ & 44 & Wood and articles of wood, wood charcoal & 0.0107 & 0.1740 \\
\hline 13 & $\mathrm{H} 4$ & 73 & Articles of iron or steel & 0.2018 & 0.3251 \\
\hline 14 & $\mathrm{H} 4$ & 78 & Lead and articles thereof & 0.0577 & 0.0027 \\
\hline 15 & $\mathrm{H} 4$ & 83 & Miscellaneous articles of base metal & 0.8703 & 1.1012 \\
\hline 16 & $\mathrm{H} 4$ & 28 & Inorganic chemicals, precious metal compound, isotopes & 0.4135 & 0.8072 \\
\hline 17 & $\mathrm{H} 4$ & 68 & $\begin{array}{l}\text { Articles of stone, plaster, cement, asbestos, mica or similar } \\
\text { materials }\end{array}$ & 0.1088 & 0.4222 \\
\hline 18 & $\mathrm{H} 4$ & 99 & Commodities not elsewhere specified & 0.0000 & 0.2802 \\
\hline 19 & $\mathrm{H} 4$ & 17 & Sugars and sugar confectionery & 0.0581 & 1.3388 \\
\hline 20 & H4 & 48 & $\begin{array}{l}\text { Paper and paperboard; articles of paper pulp, of paper or of } \\
\text { paperboard }\end{array}$ & 0.2755 & 0.7059 \\
\hline
\end{tabular}

Source: Author's own calculation, computed from the data extracted from ITC calculations based on UN COMTRADE statistic.

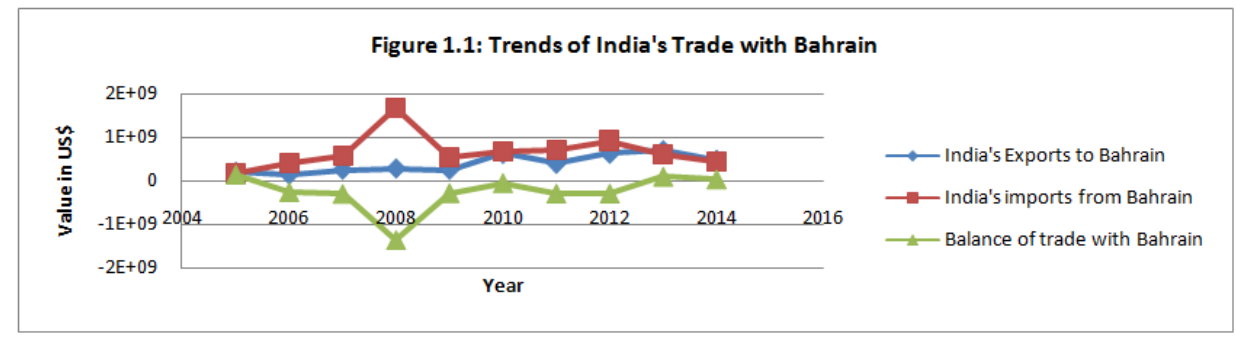

Source: Table 1

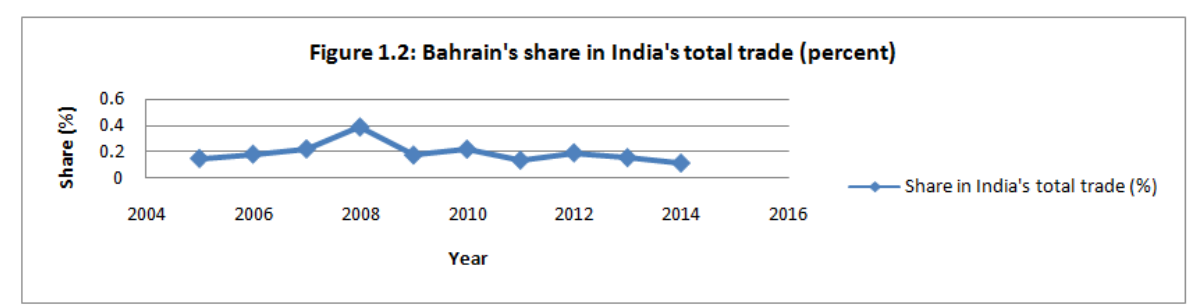

Source: Table 1

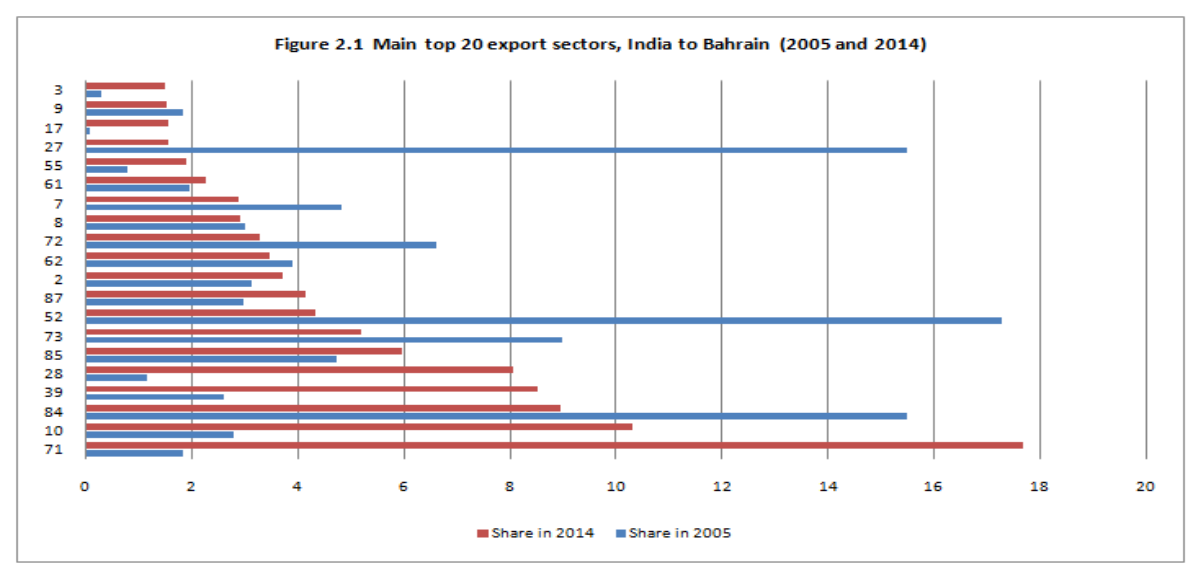

Source: Table 2.1 


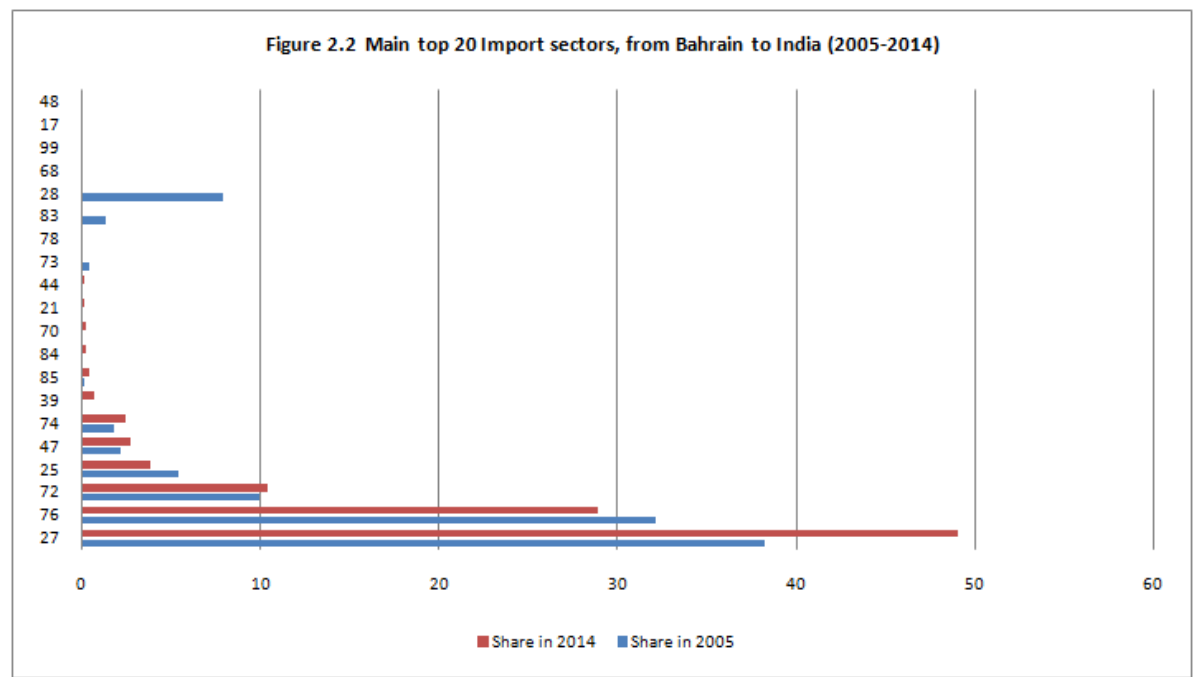

Source: Table 2.2

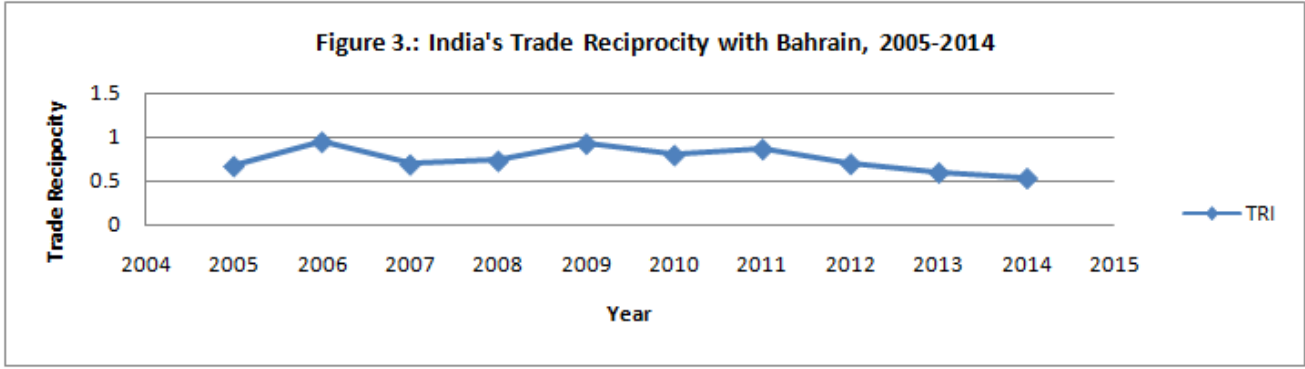

Source: Table 3

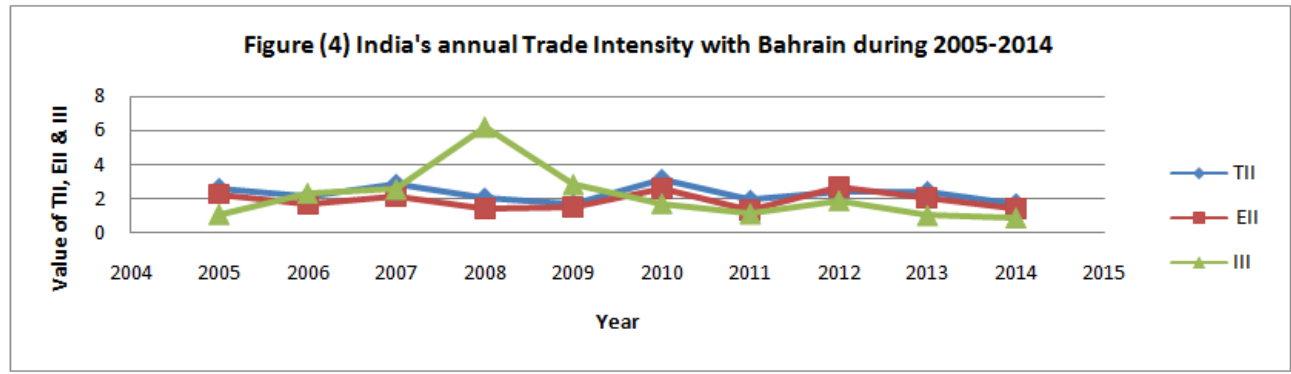

Source: Table 4

\section{Conclusion}

In this paper we examined the strength of the trade relations by estimating trends, trade composition, trade reciprocity indices and trade (export and import) intensity indices. The results show that India's trade relations with Bahrain has strengthened and improved over time, but India's export basket is not only characterised by high concentration but also thinly spread shares across a wide range of sectors. The trade reciprocity indices between India and Bahrain has not been constant over years, hence further economic integration effort is needed to move towards balanced trade. On the basis of revealed comparative advantage, we conclude that there are several potential sectors of India's export interest in the Bahrain. In the traded commodities both countries are comparatively advantageous in 72- Iron and steel and 17- Sugars and sugar confectionery and comparatively disadvantageous in 85- Electrical, electronic equipment and 28- Inorganic chemicals, precious metal compound, isotopes. However, Bahrain is comparatively advantageous in 27- Mineral fuels, mineral oils and products of their distillation; while India is comparatively advantageous in 73- Articles of iron or steel. Thus, it suggests that these countries do not compete in many areas of merchandise trade; hence there are potential economic benefits to be gained from specialisation following bilateral trade liberalisation. However, these advantages are relatively weak, with RCA values of less than 3 for both countries. Both in 2005 and 2014, sectors where only India is advantageously placed lie predominantly in the agriculture and allied products category. This advantage has been further consolidated in the year 2014. But, India holds strong 
relative comparative advantage for 71- Natural or cultured pearls, precious or semi-precious stones, precious metals, metals clad with precious metal, and articles thereof; imitation jewellery; coin, 52- Cotton, 10- Cereals, 9- Coffee, tea, mate and spices and 55- Man-made staple fibres. Bahrain, on the other hand is relatively advantageously placed in the global market only for 27-Mineral fuels, mineral oils and products of their distillation and 76-Aluminium and articles thereof. However, in 2014 Bahrain gained comparative advantage in sectors like 72- Iron and steel, 83-Miscellaneous articles of base metal, 21-Miscellaneous edible preparations and 17- Sugars and sugar confectionery.

The above quantitative analysis suggests that India's trade with the Bahrain has not achieved optimal outcomes even though huge potential exists for commercial transactions based on comparative advantage/disadvantage and competitive advantage between these two regions. Through this exercise, Indian exporters can easily identify their areas of global revealed comparative advantage in re-examining the feasibility of exporting such items which are not yet exported to the Bahrain. The main categories in which there are potential for India to expand trade are: 7-Edible vegetables and certain roots and tubers, 73- Articles of iron or steel, 72- Iron and steel, 2-Meat and edible meat offal and 27- Mineral fuels, mineral oils and products of their distillation; bituminous substances; mineral waxes.

\section{References}

[1]. Balassa, Bela. “Trade Liberalisation and 'revealed' comparative advantage.” The Manchester School, 1965: 33:99-123.

[2]. Balassa, Bela. "Revealed' Comparative Advantage Revisited: An Analysis of Relative Export Shares of the Industrial Countries, 1953-1971.” The Manchester School of Economic \& Social Studies, 45(4), 1977: 327-344.

[3]. Elmadani, Abdulla. Historical Links between India and the Gulf: from Ancient Times up to India's. United Kingdom: University of Exeter, 1999.

[4]. Richardson, David J, and Chi Zhang. Revealing Comparative Advantage: Chaotic or Coherent Patterns Across Time and Sector and U.S Trading Partner? National Bureau of Economic Research, Working Paper 7212, 1999.

[5]. Chandra, Satish. Medieval India: from Sultanate to the Mughals; 1526-1748. New Delhi: Har-Anand Publications, 1999.

[6]. Pradhan, Samir Ranjan. "India's Export Potential to the Gulf Cooperation Council (GCC) Countries: A Gravity Model Analysis." IUP Journal of Applied Economics (UNESCA), 2006: 48-71.

[7]. Jain, P C. Indian Diaspora in West Asia: A Reader. New Delhi: Manohar Publications, 2007.

[8]. Abraham, Reena. Foot Prints in Time: the Story of Indians in Bahrain. Manama, Bahrain: Miracle publications, 2008.

[9]. Rishabh, Kumar, and Rajiv Ranjan. "Evolution of Indo-GCC Trade Relations: The Last Two DEcades." International Journal of Economics, Commerce and Research, 2012: 1-8.

[10]. Ladez, Saeed Rigi, and Mohd Asef Khan. "Trade relations between India and Gulf cooperation council countries- An Emperical Study." International Research Journal of Business and Management, 2014: 41-47.

[11]. Das, Prasann Kumar, and Samir Ranjan Pradhan. "India-Gulf Trade Relations." IOSR Journal of Economics and Finance (IOSRJEF), 2014: 31-41.

[12]. Wadhva, C D, and M G Asher. Asean-South Asia economic relations. Singapore: Institute of Southeast Asian Studies, 1985.

[13]. Lei, C K, and S Yao. Economic Convergence in Greater China: Mainland China, Hong. Canada: Taylor \& Francis, 2009.

[14]. Kojima, K. "The pattern of international trade among advanced countries." Hitotsuboshi Journal of Economics, 1964: 5 (1). 